\title{
Reproductive performance of indigenous and HF crossbred dairy cows in Gondar, Ethiopia
}

\author{
Niraj Kumar ${ }^{1}$, Alemayehu Eshetie ${ }^{1}$, Berihu Gebrekidan ${ }^{1} \&$ \\ Endale Balcha Gurmu ${ }^{1}$ \\ (College of Veterinary Medicine, Mekelle University, Ethiopia)
}

\begin{abstract}
The study was conducted on altogether 411 milch animals comprising of 172 indigenous and 239 Holstein-Friesian (HF) crossbred cows maintained under farmer's managemental system in and around Gondar (Ethiopia). Collected data were analyzed according to Least Squares Analysis to study the magnitude as well as direction of variation in their days open (DO), calving interval (CI) and number of services per conception (NSC) due to genetic and some non-genetic factors. The overall Least Squares Means for DO, CI and NSC were estimated to be $116.52 \pm 42.51$ days, $439.03 \pm 66.34$ days and $1.8 \pm 0.3$ respectively. The genetic constitution of the animals influenced DO, CI and NSC significantly $(P<0.01)$. Location of herd had also significant $(P<0.05)$ effect on DO, CI and NSC. Lactation order had significant $(P<0.01)$ effect on CI and NSC. Its effect on $D O$ was also found to be significant $(P<0.05)$. Variations in all the traits due to herd-size, season of calving and farming system were statistically non-significant.
\end{abstract}

Key words: Calving interval, days open, service per conception.

\section{Introduction}

Ethiopia is believed to have the largest livestock population in Africa. This livestock sector has been contributing considerable portion to the economy of the country, and still promising to rally round the economic development of the country. The total cattle population for the country is estimated to be about 53.99 million. Out of this the female cattle constitute about 55.48 percent and the remaining 44.52 percent are male cattle. 98.95 percent of the total cattle in the country are local breeds and remaining are hybrid and exotic breeds that accounted for about 0.94 percent and 0.11 percent, respectively [1]. Despite the largest cattle population, productive and reproductive performance is very low. Feed shortage (both in terms of quantity and quality), lack of access to land, disease prevalence, low level of management, lack of proper poor breeding management such as lack of accurate heat detection and timely insemination might have contributed considerably to long days open (postpartum anestrous), late age at first calving, long calving interval, short lactation length and low milk production [2].

In order to improve the low productivity of local cattle, selection as well as cross breeding of these indigenous breed with high producing exotic cattle has been considered as a practical solution [3]. Crossbreeding work in Ethiopia was initiated in the early 1950s but the crossbreeding activities, unfortunately, were not based on clearly defined breeding policy with regard to the level of exotic inheritance and the breed types to be used. The unplanned crossbreeding had also threatened the genetic resources base of the country. Although efforts were made at developing breeding program for various livestock species in the country, all did not materialize due to lack of commitment of and consultation with various stakeholders [4].

The reproductive performance of the breeding female is probably the single most important factor that is a prerequisite for sustainable dairy production system and influencing the productivity [5]. Number of services per conception, days opens till conception and calving interval are important reproductive traits which are crucial for determining the profitability of dairy production [6]. Currently, a large number of smallholder crossbred dairy farms are operating in the study area. However, information on productive and reproductive performance of crossbred dairy cows in the study area is limited. Most of the research conducted has been under relatively controlled conditions at research centers and government-owned institutions and thus has limited application to different production systems in Africa [7].

The present investigation was undertaken to study the effect of genetic and various non-genetic factors on DO, CI and NSC in indigenous as well as crossbred cattle maintained in small dairy units under farmer's management located in and around Gondar city (Ethiopia) with an objective to identify the significance of the genetic and different non-genetic factors in optimizing their reproductive efficiency and thus, economic milk production. 


\section{Materials And Methods}

\subsection{Study area}

The study was conducted in and $10 \mathrm{~km}$ around Gondar city, Amhara National Regional State, located in the northwestern part of Ethiopia. Study area located between 700 and $778 \mathrm{kms}$ northwest of the capital, Addis Ababa. The study zone is located between geographically coordinates $12.3^{\circ}$ to $13.38^{\circ}$ north latitudes and $35.5^{\circ}$ to $38.3^{\circ}$ east longitudes and the altitude ranges from 550 to 4620 meters above sea level (masl) in western lowland and in north Semen Mountain, respectively. The average annual rain fall vary from $880 \mathrm{~mm}$ to $1772 \mathrm{~mm}$, which is characterized by a monomodal type of distribution. The mean annual minimum and maximum temperature is $10^{\circ} \mathrm{C}$ in the highland and $44.5^{\circ} \mathrm{C}$ in the lowland [8].

\subsection{Study population and sampling procedure}

A total of 411 milch animals comprising of 172 indigenous and $239 \mathrm{HF}$ crossbred cows from 86 smallholder dairy farmers in and around Gondar city of Ethiopia. Farmers were interviewed randomly with scheduled questionnaire which was mainly based on the reproductive performance information of Indigenous and HF crossbred dairy cows. The questionnaire was developed in accordance with the objectives of the study and designed in a simple manner to get accurate information from the dairy farm owners. Each respondent was given a brief description about the nature and purpose of the study.

The entire study area was divided into two zones viz. urban which constitute the city area and periurban constitute in a radius of about $10 \mathrm{~km}$ around city. The private dairy units were grouped into three groups on the basis of number of milch animals they possessed and delineated as herds of sizes up to 3, 4-6 and 7 and above. To study the influence of season of calving on different economic traits, the year was divided into three seasons viz. Hot-dry (March-June), Hot-humid (July-October) and Cold (November-February). Performance records of milch animals in first to fifth lactation were only included. On the basis of the farming system adopted by the farmers, the units were classified into two types i.e. household exclusive doing animal husbandry and those doing animal husbandry integrated with crop-production. Days open (DO), calving interval (CI) and number of services per conception (NSC) were traits taken as the measures of reproduction efficiency in this study. Stratified random sampling with proportional allocation [9] was adopted for selection of respondent units.

\subsection{Data analysis}

Data collected were subjected to Least Squares Analysis [10] for which the following mathematical model was utilized:

$$
\mathrm{Y}_{\mathrm{ijklmnp}} \quad=\quad \mu+\mathrm{G}_{\mathrm{i}}+\mathrm{Z}_{\mathrm{j}}+\mathrm{F}_{\mathrm{k}}+\mathrm{HS}_{1}+\mathrm{S}_{\mathrm{m}}+\mathrm{P}_{\mathrm{n}}+\mathrm{e}_{\mathrm{ijklmn}}
$$

Where,

$\mathrm{Y}_{\mathrm{ijklmnp}} \quad=\quad$ the value of $\mathrm{p}^{\text {th }}$ individual under $\mathrm{i}^{\text {th }}$ genetic group, $\mathrm{j}^{\text {th }}$ zone, $\mathrm{k}^{\text {th }}$ farming system, $^{\text {th }}$ herd size, $\mathrm{m}^{\text {th }}$ season of calving and $\mathrm{n}^{\text {th }}$ parity.

$\mu \quad=\quad$ the population mean.

$\mathrm{G}_{\mathrm{i}} \quad=\quad$ the effect of $\mathrm{i}^{\text {th }}$ genetic group $(\mathrm{i}=1,2)$

$\mathrm{Z}_{\mathrm{j}} \quad=\quad$ the effect of $\mathrm{j}^{\text {th }}$ location herd $(\mathrm{j}=1,2)$

$\mathrm{F}_{\mathrm{k}} \quad=\quad$ the effect of $\mathrm{k}^{\text {th }}$ farming system $(\mathrm{k}=1,2)$

$\mathrm{HS}_{1} \quad=\quad$ the effect of $\mathrm{l}^{\text {th }}$ herd size $(1=1,2,3)$

$\mathrm{S}_{\mathrm{m}} \quad=\quad$ the effect of $\mathrm{m}^{\text {th }}$ season of calving $(\mathrm{m}=1,2,3)$

$\mathrm{P}_{\mathrm{n}} \quad=\quad$ the effect of $\mathrm{n}^{\text {th }}$ parity $(\mathrm{n}=1,2,3,4,5)$

$\mathrm{e}_{\mathrm{ijklmnp}}=$ the random error associated with individual which is randomly and independently distributed with mean zero and variance $\sigma^{2}$.

The statistical significance of various effects was tested by "F" test. Whereas, the "F" value was significant, the Duncan's Multiple Range (DMR) Test modified by [11] was utilized for pair wise comparison of the Least Square Means at 5 and 1 percent level of probability. Relevant phenotypic correlation among the economic traits was estimated utilizing standard statistical procedure [9].

\subsection{Days open}

\section{Results}

The overall Least Squares Means for DO in indigenous and HF crossbred cows included in this study were estimated to be $116.52 \pm 42.51$ days (Table-2). Genetic group had significant $(\mathrm{P} \leq 0.01)$ influence on DO, its contribution to the total variation in the trait being $7.05 \%$ (table-1). The indigenous cows had significantly higher average DO (148.33 \pm 38.44 days) than that of HF crossbred ( $93.11 \pm 43.87$ days). Variation in zone had also significant $(\mathrm{P} \leq 0.05)$ influence DO (table-1). The peri-urban zone of study area had significantly higher average DO (130.01 \pm 52.61 days) than that of urban zone (104.23 \pm 28.81 days). The effect of hard-size and season of calving on DO was statistically not significant (table-1). Lactation order (parity) effect contributed 
significantly $(\mathrm{P} \leq 0.05)$ to the total variation in $\mathrm{DO}$ and the magnitudes of contributions being $2.30 \%$ (table-1). The mean DO was significantly longer in the first calvers (134.34 \pm 50.23 days) followed by fourth (116.49 \pm 48.22 days), fifth (114.33 \pm 29.36 days), third (113.31 \pm 33.98 days) and second (111.82 \pm 32.64 days) calvers (Table-2). The farming system did not have any significant influence on DO.

Table-1: Least square analysis of variance showing effects of genetic and non-genetic factors on days open, calving interval and number of services per conception of animals in and around Gondar (Ethiopia).

\begin{tabular}{lcccc}
\hline & & Days open (DO) & Calving interval (CI) & $\begin{array}{c}\text { Number of services per } \\
\text { conception (NSC) }\end{array}$ \\
\hline Sources of variation & d.f. & M.S.S. & M.S.S. & M.S.S. \\
\hline Genetic group & 1 & $3738.67 * *(7.05)$ & $9655.39^{* *(10.91)}$ & $135.51^{* *(16.38)}$ \\
Zone & 1 & $141.23^{*}(0.51)$ & $462.45^{*}(0.76)$ & $0.89 *(0.96)$ \\
Herd-size & 2 & $39.52(0.06)$ & $277.83(0.42)$ & $0.45(0.68)$ \\
Season of calving & 2 & $113.94(0.22)$ & $398.36(0.60)$ & $0.69(0.78)$ \\
Lactation order & 4 & $886.43 *(2.30)$ & $1324.56^{* *(3.01)}$ & $5.02^{* *(3.67)}$ \\
Farming system & 1 & $101.28(0.45)$ & $418.25(0.66)$ & $0.04(0.01)$ \\
Residual & 399 & $399.97(89.41)$ & $378.27(83.64)$ & $18.33(77.52)$ \\
\hline
\end{tabular}

** $\mathrm{P} \leq 0.01 ; * \mathrm{P} \leq 0.05$ (Figures mentioned in parenthesis indicate co-efficient of determination $\left(\mathrm{R}^{2}\right)$.

\subsection{Calving interval}

The overall Least Squares Means for CI in indigenous and HF crossbreed cows, included in this study were estimated to be $439.03 \pm 66.34$ days (Table-2). Genetic group had significant $(\mathrm{P} \leq 0.01)$ influence on $\mathrm{CI}$, its contribution to the total variation in the trait being $10.91 \%$. Indigenous cows had the significantly longer average CI (453.22 \pm 71.81 days) than that of HF crossbreds cows (428.11 \pm 64.32 days). Variation in zone had also significant $(\mathrm{P} \leq 0.05)$ influence $\mathrm{CI}$ (table-1). The peri-urban zone of study area had significantly higher average CI (458.77 \pm 71.85 days) than that of urban zone (420.22 \pm 55.43 days). The effect of hard-size and season of calving on CI was also statistically not significant (table-1). Parity effect contributed significantly $(\mathrm{P} \leq 0.01)$ to the total variation in $\mathrm{CI}$, the magnitudes of contributions being $3.01 \%$ (table-1). The first calvers (459.33 \pm 45.77 days) was significantly longer than fourth (436.61 \pm 66.56 days), fifth (436.22 \pm 71.09 days), third (435.74 \pm 69.34 days) and second (431.51 \pm 71.67 days) which did not differ significantly among each other. The farming system did not have any significant influence on CI.

\subsection{Number of services per conception}

The overall Least Squares Means for NSC in the present study was 1.8 \pm 0.3 . Genetic group had significant $(\mathrm{P} \leq 0.01)$ influence on NSC, its contribution to the total variation in the trait being $16.38 \%$. Indigenous cows had the significantly higher NSC (2.2 \pm 0.2$)$ than that of HF crossbreds (1.5 \pm 0.3$)$. Variation in zone had also significant $(\mathrm{P} \leq 0.05)$ influence on NSC (table-1). The peri-urban zone of study area had significantly higher average NSC (2.0 \pm 0.4$)$ than that of urban zone (1.6 \pm 0.2$)$. Herd size and season of calving did not influence NSC significantly (table-1). Parity effect contributed significantly ( $\mathrm{P} \leq 0.01$ ) to the total variation in NSC, the magnitudes of contributions being 3.67\% (table-1). The first (2.2 \pm 0.4$)$ NSC was significantly larger than fifth $(1.8 \pm 0.3)$, second $(1.7 \pm 0.3)$, third $(1.7 \pm 0.3)$ and fifth (1.6 \pm 0.2$)$. The farming system did not have any significant influence on NSC.

Table-2: Least square means days open, calving Interval and number of services under genetic and non-genetic factors in animals in and around Gondar (Ethiopia).

\begin{tabular}{|c|c|c|c|}
\hline & Days open (days) & Calving Interval (days) & $\begin{array}{c}\text { Number of services per } \\
\text { conception }\end{array}$ \\
\hline & Mean \pm S.E & Mean \pm S.E & Mean \pm S.E \\
\hline Overall mean $(\mu)$ & $116.52 \pm 42.51$ & $439.03 \pm 66.34$ & $1.8 \pm 0.3$ \\
\hline \multicolumn{4}{|l|}{ Factors } \\
\hline \multicolumn{4}{|l|}{ Genetic Groups } \\
\hline Indigenous cow & $148.33^{\mathrm{a}} \pm 38.44$ & $453.22^{\mathrm{a}} \pm 71.81$ & $2.2^{\mathrm{a}} \pm 0.2$ \\
\hline HF crossbred & $93.11^{\mathrm{b}} \pm 43.87$ & $428.11^{\mathrm{b}} \pm 64.32$ & $1.5^{\mathrm{b}} \pm 0.3$ \\
\hline \multicolumn{4}{|l|}{ Zones } \\
\hline Urban & $104.23^{\mathrm{a}} \pm 28.81$ & $420.22^{\mathrm{a}} \pm 55.43$ & $1.6^{\mathrm{a}} \pm 0.2$ \\
\hline Peri-urban & $130.01^{\mathrm{b}} \pm 52.61$ & $458.77^{\mathrm{b}} \pm 71.85$ & $2.0^{\mathrm{b}} \pm 0.4$ \\
\hline \multicolumn{4}{|l|}{ Herd-sizes } \\
\hline (Up to 3 ) animals & $118.23 \pm 38.11$ & $443.55 \pm 69.12$ & $1.8 \pm 0.4$ \\
\hline
\end{tabular}


Reproductive performance of indigenous and HF crossbred dairy cows in Gondar, Ethiopia

\begin{tabular}{|c|c|c|c|}
\hline (4-6) animals & $114.71 \pm 41.53$ & $434.29 \pm 55.34$ & $1.8 \pm 0.3$ \\
\hline (7 \& above) animals & $113.98 \pm 46.32$ & $435.11 \pm 60.22$ & $1.7 \pm 0.3$ \\
\hline \multicolumn{4}{|l|}{ Seasons of calving } \\
\hline Mar. - June & $119.38 \pm 45.43$ & $444.45 \pm 49.34$ & $1.9 \pm 0.3$ \\
\hline July - Oct. & $113.22 \pm 44.31$ & $432.56 \pm 35.56$ & $1.7 \pm 0.3$ \\
\hline Nov. - Feb. & $116.45 \pm 35.86$ & $435.69 \pm 78.76$ & $1.8 \pm 0.2$ \\
\hline \multicolumn{4}{|l|}{ Parities } \\
\hline $1^{\text {st }}$ & $134.34^{\mathrm{a}} \pm 50.23$ & $459.33^{\mathrm{a}} \pm 45.77$ & $2.2^{\mathrm{a}} \pm 0.4$ \\
\hline $2^{\text {nd }}$ & $111.82^{\mathrm{b}} \pm 32.64$ & $431.51^{\mathrm{b}} \pm 71.67$ & $1.7^{\mathrm{b}} \pm 0.3$ \\
\hline $3^{\text {rd }}$ & $113.31^{\mathrm{b}} \pm 33.98$ & $435.74^{\mathrm{b}} \pm 69.34$ & $1.7^{\mathrm{b}} \pm 0.3$ \\
\hline $4^{\text {th }}$ & $116.49^{\mathrm{b}} \pm 48.22$ & $436.61^{\mathrm{b}} \pm 66.56$ & $1.6^{\mathrm{b}} \pm 0.2$ \\
\hline $5^{\text {th }}$ & $114.33^{\mathrm{b}} \pm 29.36$ & $436.22^{\mathrm{b}} \pm 71.09$ & $1.8^{\mathrm{b}} \pm 0.3$ \\
\hline \multicolumn{4}{|l|}{ Farming systems } \\
\hline $\begin{array}{ll}\text { Only } & \text { animal } \\
\text { husbandry }\end{array}$ & $118.33 \pm 44.34$ & $438.43 \pm 60.23$ & $1.8 \pm 0.3$ \\
\hline Mixed farming & $115.00 \pm 40.65$ & $441.23 \pm 73.34$ & $1.8 \pm 0.3$ \\
\hline
\end{tabular}

\# Values superscripted by similar letter were not significantly different from each other.

\section{Discussions}

The estimated value for DO was higher than the optimum values desirable for profitable milk production. It is generally believed that milk yield is affected by the preceding dry period. Considering the biological limits and economics of the operation involved, many workers in tropical and sub-tropical regions have set a range of 40-60 days as an optimum dry period for the perspective of cow's health and farmer's profit. The findings of estimated DO was higher than 85.6 \pm 5.6 days reported in Asella town, Oromia regional state, Ethiopia [12] and $2.9 \pm 3.7$ months reported in crossbred cattle in and around Gondar, North Western Ethiopia [13]. Shorter DO of $148 \pm 1.72$ days reported in dairy cows in urban and peri-urban dairy production system of Addis Ababa milk-shade [14] and 5.19 \pm 1.72 months in Zebu X Holstein-Friesian crossbred dairy cows in Jimma Town, Oromia, Ethiopia [2]. Indigenous cows are also included in the present investigation might be important contributory factor for high DO. Feed shortage, silent estrus and lack of proper heat detection might have other contributory factors for long DO reported in this study.

Although DO is supposed to be influenced mainly by non-genetic causes, more genetic divergence among crossbred cattle and indigenous cows might have resulted into expression of genetic effect on DO to be significant in this investigation. Influence of genetic-constitution of dairy animals on their DO reported to be significant in Arsi and Zebu breeds of cows and its crosses with Jersey and Holstein-Friesian in Arsi region of Ethiopia [5]. Higher DO in peri-urban area may be attributed to the fact that the AI facilities in urban area are better than the peri-urban zone. Effect of herd size on DO of indigenous and crossbred cows was also reported to be non significant in sub tropical region [15]. No definite trend in variation in DO due to parity could be established in this study. Influence of parity of dairy animals on their respective DO was also reported to be non significant in Arsi and Zebu breeds of cows and its crosses with Jersey and Holstein-Friesian in Arsi region of Ethiopia [5]. The difference in finding may be attributed to difference in location and management of study area. The findings of this study were more or less in agreement with the result of other work in sub tropical region $[15,16]$.

The estimate of CI was higher than the optimum values desirable for profitable milk production. CI of 365 days is usually considered ideal for profitable milk production [17]. Therefore, the CI, as seen in this study, suggest a large need for future improvement. Higher CI of 372.8 days reported in Asella town, Oromia regional state, Ethiopia [12] and $13.4 \pm 5.1$ months in crossbred cattle in and around Gondar, North Western Ethiopia [13]. This estimated CI in this study was less than 21.36 \pm 3.84 months in Zebu X Holstein-Friesian crossbred dairy cows in Jimma Town, Oromia, Ethiopia [2], 487 days in crossbred dairy cows in different production systems in the central Highlands of Ethiopia [18]; 552 days in Boran cattle and their Friesian crosses at Abernossa Ranch, Ethiopia [19] and 475 days in crossbred cattle in Central Ethiopia [20]. Indigenous cows are also included in the present investigation might be important contributory factor for high CI. Feed shortage, silent estrus and lack of proper heat detection might have other contributory factors for long CI reported in this study. Influence of genetic-constitution of dairy animals on their CI was also reported to be significant in Arsi and Zebu breeds of cows and its crosses with Jersey and Holstein-Friesian in Arsi region of Ethiopia [5] and in indigenous and crossbred cows in private sector in sub tropical region [16, 21]. The effect of herd-size on CI was reported to be significant in sub tropical region [22]. It was contrary to the findings of this study and may be attributed to variation in the size of the herd as well as genetic constitution of the experimental animals in different studies. The influence of season of calving on CI was also reported to be non significant in Arsi and Zebu breeds of cows and its crosses with Jersey and Holstein-Friesian in Arsi region of Ethiopia [5]. Significantly longer CI corresponding to first parity may plausibly be attributed to longest DO in the corresponding parity. The trend of variation in CI due to parity difference was similar to that for DO. The influence of parity on CI was reported to be significant in Arsi and Zebu breeds of cows and its crosses with 
Jersey and Holstein-Friesian in Arsi region of Ethiopia [5] and indigenous as well as crossbred cows in sub tropical region [16].

NSC higher than 2 should be considered as poor [23]. NSC depends largely on the breeding system used. It is higher under uncontrolled natural breeding than hand-mating and artificial insemination [24]. The overall Least Squares Means for NSC is more or less in agreement with 1.8 for crossbred cows in Ethiopia [14] and 1.7 reported in the highlands of Ethiopia [6]. The findings of estimated NSC were lower than 2.0 as reported in dairy cows at Asella Livestock farm [25]. The estimated NSC was higher than 1.62 as reported in crossbred dairy cows in different production systems in the central Highlands of Ethiopia [18]; 1.62 as reported in crossbred dairy cows in central Ethiopia [20]; 1.67 as reported in mid Rift valley of Ethiopia [26]; 1.3 as reported for crossbred cows in Gondar city of Ethiopia [13] and 1.52 reported from Assela town of Oromia region of Ethiopia [12]. The differences could be attributed to differences in management practices and agroecology of the respective areas. Influence of genetic-constitution of dairy animals on their NSC was also reported to be significant in three local Ethiopian breeds, the Barca, Horro and Boran and crossbred cows [27]. Lower NSC value in urban area might be due to better veterinary services and AI facilities. Feed shortage, poor reproductive management, lack of proper heat detection and lack of time insemination might have the most plausible explanation for high NSC recorded in this study.

\section{CONCLUSION}

Reproductive performance of dairy cows in the resent study was found to be lesser than the optimum values desirable for profitable milk production. On the basis of the finding, it could be suggested that Friesian crossbred cows in and above second parity had relatively better reproductive efficiency in the agro-climatic condition of Gondar, Ethiopia for profitable milk production.

\section{References}

[1] CSA 2012/13. Agricultural sample survey. Report on livestock and livestock characteristics. The Federal Democratic republic of Ethiopia, Central Statistical Agency (CSA). Private Peasant Holdings. Statistical Bulletin 570, Addis Ababa, Ethiopia, April, 2013

[2] Belay, D., Yisehak, K. and Janssens, G.P.J. 2012. Productive and Reproductive Performance of Zebu X Holstein-Friesian Crossbred Dairy Cows in Jimma Town, Oromia, Ethiopia. Global Veterinaria 8 (1): 67-72.

[3] Tadesse, B. 2002. Reproductive performances of zebu (Fogera) breed in the central highlands of Ethiopia. DVM thesis, Addis Ababa University, Faculty of Veterinary Medicine, Debre Zeit, Ethiopia.

[4] Aynalem, H., Workneh, A., Noah K., Tadelle D. and Azage T. 2011. Breeding strategy to improve Ethiopian Boran cattle for meat and milk production. IPMS (Improving Productivity and Market Success) of Ethiopian Farmers Project Working Paper 26. Nairobi, Kenya, ILRI.

[5] Kiwuwa, G.H., Trail, J.C.M., Kurtu, M.Y. Worku, G. Anderson F.M. and Durkin J. (1983) Crossbred dairy cattle productivity in Arsi region, Ethiopia (Research report No. 11, ILCA, Addis Ababa, Ethiopia), pp: 1-29.

[6] Lobago, F., Bekana, M., Gustafsson, H. and Kindahl, H. 2007. Longitudinal observation on reproductive and lactation performances of smallholder crossbred dairy cattle in Fitche, Oromia region, central Ethiopia, Tropical Animal Health and Production, 39: 395403.

[7] Shiferaw, Y., Tenhagen, B.A., Bekena, M. and Kassa, T. 2001. Productive performance of crossbred dairy cows in different production system in Central Highland of Ethiopia. Tropical Animal Health and Production, 35 (2003): 551-561

[8] National Meteorological agency (NMA), (2011) Annual Climatical Bulletin for the year 2011. National Metrological Agency of Ethiopia.

[9] Snedecor, G.W. and Cochran, W.G. 1967. Statistical methods, Iowa State Univ. Press, Ames, Iowa, USA

[10] Harvey, W.R. 1966. Least Square Analysis of data with unequal sub-class numbers. U. S. Deptt. of Agriculture, A.R.S

[11] Kramer, C.Y. 1957. Extension of Multiple Range Test to group correlated adjusted means. Biometrics.13: 13-17.

[12] Hunduma, D. 2012. Reproductive performance of crossbred dairy cows under smallholder condition in Ethiopia. International Journal of Livestock Production. 3(3): 25-28.

[13] Nibret, M. 2012. Study on Reproductive Performance of Crossbred Dairy Cows under Small Holder Conditions in and Around Gondar, North Western Ethiopia. Journal of Reproduction and Infertility. 3 (3): 38-41.

[14] Tadesse, M., Thiengtham, J., Pinyopummin, A. and Prasanpanich, S. 2010. Productive and reproductive performance of Holstein Friesian dairy cows in Ethiopia. Livestock Research for Rural Development. 22 (2):21

[15] Kumar, N. 2005. Genetic analysis of milk production efficiency of cattle and buffalo in and around Darbhanga, Bihar. MVSc thesis submitted to Rajendra Agricultural University, Pusa, Bihar, India.

[16] Rao, S.J., Rao, B.V.R. and Rao, G.N. 2000. Performance of crossbred cows and buffaloes under village conditions of Visakhapattanam district of Andhra Pradesh. Indian Journal of Dairy Science. 53 (3): 222-226.

[17] Khan, U.N., Olsson, A. and Philipsson, J. 1992. Sahiwal herd development in Pakistan. Anim. Prod. Rural Deve. Proc. 6th Asian Association for Animal Production (AAAP), Annual Congress, Vol. I. Bangkok, Thailand.

[18] Shiferaw, Y., Tenhagn, B.A., Bekana, M. and Kassa, T. 2003. Reproductive performance of crossbred Dairy cows in different production systems in the central Highlands of Ethiopia. Tropical Animal Health Production. 25: 551-561.

[19] Haile-mariam, M., Banjaw, K., Gebremeskel, J. and Ketema, T. 1993. Productivity of Boran Cattle and their Friesian crosses at Abernossa Ranch, Ethiopia. I. Reproductive performance and prevailing mortality. Tropical Animal Health Production. 25: 239-248.

[20] Bekele, T., Kasali, O.B. and Alemu, T. 1991. Reproductive problems in crossbred cattle in Central Ethiopia. Animal Production Science. 26: 41-49.

[21] Singh, K., Khanna, A.S. and Kanaudia, A.S. 2000. Factor effecting lactation performance and persistency in crossbred cattle. India Journal of Dairy Science. 53 (5): 354-360.

[22] Shrivastava, A.K., Singh, C.S.P., Verma, S.K. and Singh, R.A. 1996. Effect of various factors on dry-period and claving-interval in Zebu x Friesian crossbred cows maintained under farmer's managemental conditions. Indian Veterinary Medical Journal. 20 (3): 202-206. 
[23] Mukasa-Mugerewa, E. 1989. A review of reproductive performance of female Bos indicus (Zebu) cattle, International Livestock Centre for Africa (ILCA), monograph, Addis Ababa, Ethiopia.

[24] Gabriel, H.K., John, C.M., Trail, M.Y., Kurtu, G.W., Frank, M.A. and Jeffrey, D. 1983. Crossbred dairy cattle productivity in Arsi Region, Ethiopia. ILCA Research Report No. 11

[25] Negussie, E., Brannang, E., Banjaw, K. and Rottmann, O.U. 1998. Reproductive performance of dairy cattle at Assella livestock farm. Arsi. Ethiopia. I: Indigenous cows versus their F1 crosses. J. Anim. Breed. Genet., 115: 267-280.

[26] Yifat, D., Kelay, B., Bekana, M., Lobago, F., Gustafsson, H. and Kindahl, H. 2009. Study on reproductive performance of crossbred dairy cattle under smallholder conditions in and around Zeway, Ethiopia. Livestock Research for Rural Development. 21(6). http://www.lrrd.org/lrrd21/6/yifa21088.htm

[27] Azage, T., Galal, E.S.E. and Beyene, K. 1981. A study on the reproduction of local zebu and F1 crossbred (European x zebu) cows. I. Number of services per conception, gestation length and days open till conception. Ethiopian Journal of Agricultural Sciences 3: 114. 